Sources, Materials, Miscellanea

http://dx.doi.org/10.15762/ZH.2018.20

KONRAD BOBIATYŃSKI

(University of Warsaw)

ZBIGNIEW HUNDERT

(Cardinal Stefan Wyszyński University in Warsaw)

\title{
The Composition of the Army of the Grand Duchy \\ of Lithuania DURING THE WAR With TuRkey (1675-1676) in the Light of Financial and Military files*
}

Key words: the Polish-Turkish war 1672-1676, the Lithuanian army, Old-Polish warfare

The participation of the army of the Grand Duchy of Lithuania in the war between the Polish-Lithuanian Commonwealth and the Ottoman Empire in the years $1672-1676$, like the conflict itself ${ }^{1}$, has been extensively presented in the literature. The monographs concern not only subsequent stages of military activities, in which the Lithuanian army participated, but also a number of organizational and political aspects which affected the attitude of the Grand Duchy of Lithuania ${ }^{2}$. In the current stage of the research we are familiar with

* The article was written as part of the grant of the National Programme for the Development of Humanities no. 11H 13033482 titled Treasury files as the source for the history of OldPolish warfare under the reign of the House of Vasa carried out in the years 2015-2020.

${ }^{1}$ Mainly: Marek WAGNER, Wojna polsko-turecka 1672-1676, t. 1-2, Zabrze 2009; see also: Zbigniew HUNDERT, Husaria koronna w wojnie polsko-tureckiej 1672-1676, Oświęcim 20142, pp. 323-417 - here references to the literature of the subject matter.

${ }^{2}$ We should enumerate: Aleksander CodeLLO, Litwa wobec wojny z Turcja 1672-1676, Studia i Materiały do Historii Wojskowości (further cit. SMHW), t. 13: 1970, cz. 1, pp. 136-159; Anna Filipczak-Kocur, Od Chocimia do Żórawna (Żurawna). Finansowy udział Wielkiego Księstwa Litewskiego w kampaniach wojennych 1673-1676, [in:] Studia historyczno-wojskowe, t. 3, ed. Tomasz Ciesielski, Zabrze 2009, pp. 130-137 (the English version: The financial contribiution of the Grand Duchy of Lithuania to the war campaigns in the years 1673-1676, [in:] Prablyemy intehratsyi i inkarparatsyi $w$ razvitstsi Tsentaral'nay $i$ Uskhodnyay Yewropy w pyeryyaad rannyaha Novaha chasu, ed. Stsyapan Sokal, Andrey Yanushкyevich, Minsk 2010 [Праблемы інтэграиьы і інкарпаращьы ў развіциі Цэнтаральнай і Усходняй Еўропы ў перыяад ранняга Новага часу, рэд. Сияпан Сокал, Андрэй Янушкевіч, Мінск 2010], pp. 358-366); Konrad BoBIATYŃsKI, Wojsko i polityka - kilka uwag o udziale armii litewskiej w kampaniach 
the exact composition of the Lithuanian army during the Battle of Khotyn [Chocim] $]^{3}$. For the subsequent periods, mostly for the years 1675-1676, the situation looks worse. So far the main source of knowledge about the size and composition of the Lithuanian army at the time were editions of manuscripts of the registers of the Lithuanian army, which were frequently misleading ${ }^{4}$. We shall try to show that most of them referred to unrealized projects, which often concerned another decade.

The basic aim of this edition is to rectify many inaccuracies in the literature of the subject matter, which have arisen owing to the uncritical use of those documents. The main source basis to reconstruct the composition of the Lithuanian army in three quarters of the service in the years 1675-1676 constituted the billings of the Grand Lithuanian Sub-Treasurer Paweł Sapieha prepared for the Grodno Sejm of 1678/79, which are easily available to Polish historians. They illustrate expenditures on individual units of the Lithuanian

przeciwko Turkom i Tatarom w latach 70. XVII w., [in:] Rzeczpospolita państwem wielu narodowości i wyznań. XVI-XVIII wiek, ed. Tomasz Ciesielski, Anna Filipczak-Kocur, Warszawa-Opole 2008, pp. 503-519 (the Belarusian version: Voyska i palityka - nyekal'ki zawvah pra wdzyel voyska Vyalikaha Knyastva Litowskaha w kampaniyakh suprats' turkaw i tataraw u 70-kh hh. XVII st. [Войска і палітыка - некалькі заўваг пра уудзел войска Вялікага Княства Літоўскага у кампаніях супраць туркаў і татараў у 70-х г2. XVII cm.], Arche, 2012, nr 6 (117), pp. 387-402); idem, W drodze pod Chocim. Litewskie przygotowania do wojny przeciwko Turkom w 1673 roku, [in:] Studia z dziejów Wielkiego Księstwa Litewskiego (XVI-XVIII wieku), ed. Mirosław NAGIELSKI, Sławomir Górzyński, Warszawa 2014, pp. 27-47; idem, Nieznana litewska relacja o bitwie pod Chocimiem w 1673 roku, Przegląd Historyczny, t. 106: 2015, z. 3, pp. 551-563; Arkadiusz MALEJKA, Zdobycie Pawołoczy (1675 r.) - epizod z wojny polsko-tureckiej, [in:] Traktaty karłowickie 1699 roku $i$ ich następstwa, red. Ilona CzAmańsKA, Witold Szulc, Balcanica Posnaniensia. Acta et Studia, t. 13: 2003, pp. 85-93. Moreover, the participation of the army of the Grand Duchy of Lithuania in military actions in the years 1673-1676 are presented in the biographies of the most important Lithuanian commanders of the time, see: Konrad Boвiatý́ski, Michał Kazimierz Pac. Wojewoda wileński, hetman wielki litewski, Warszawa 2008, pp. 285-345; idem, Michał Kazimierz Radziwiłt jako hetman polny litewski (1668-1680), [in:] Radziwiłłowie w służbie Marsa, ed. Mirosław NAGIELski, Karol ŻoJdź, Warszawa 2017, pp. 229-241; Andrzej Adam Majewski, Aleksander Hilary Połubiński (1626-1679). Marszałek wielki litewski, Warszawa 2017, pp. 431-448.

${ }^{3}$ K. Bobiatyński, $W$ drodze pod Chocim, pp. 44-47.

${ }^{4}$ First of all, editions of the military registers prepared by Janusz Woliński on the basis: Archiwum Główne Akt Dawnych in Warsaw [The Central Archives of Historical Records in Warsaw] (further cit. AGAD), Archiwum Zamoyskich, sygn. 3112, pp. 417-419, 441-442; see: Komput lewego skrzydła wojska W. Ks. Lit. in opere zostajacego, jak ad praesens zostaje [b.d. 1674/1675]; Choragwie, które $z$ ks. Jm. powróciły i wiele pod która teraz zostaje effective [b.d. 1674/1675], [in:] Sobiesciana z 1675 r., ed. Janusz Wolıński, Przegląd Historyczno-Wojskowy, t. 5: 1932, z. 2, pp. 223-225; Komput wojsk W. Ks. L., ad opus belli [1675], [in:] Materiały do dziejów wojny polsko-tureckiej 1672-1676, ed. Janusz WoLIŃsKI, SMHW, t. 15: 1969, cz. 2, pp. 231-232. 
army in the quarter from 15 August to 15 November 1675 and two quarters of 1676 - from 15 May to 15 November $^{5}$. It must be underlined that the materials have been already used by historians, e.g. in order to reconstruct the unitary composition of a banner of the medium cavalry - petyhorcy - in the Lithuanian army in the years 1675-1676 6 . In order to show the composition of the army in the first half of 1675, the author used the register of Lithuanian military units from the Cracow Archive of the Sanguszko Family, which seems to be the best source to present this issue.

The Lithuanian army in the war between the Polish-Lithuanian Commonwealth and the Ottoman Empire participated in all the war campaigns except the first year of the conflict, when it was under the reconstruction after the dissolution of the army in the camp near the village of Dubienka, which had taken place a year before. The reason why the army was gathered was not the threat from the Turkish army, but the necessity to support King Michał Korybut Wiśniowiecki in his struggle with the opposition. The magnitude of the reconstructed army, which in November formed the confederation in Kobryń to support the king, was estimated at 4,000 to 5,000 soldiers ${ }^{7}$. In 1673 , when the

${ }^{5}$ Liczba jaśnie wielmożnego jmści Pana Benedykta Pawła na Czerei Sapiehy, podskarbiego wielkiego, pisarza ziemskiego W. Ks. Lit., rosławskiego, retowskiego, olkiennickiego starosty. Z podatków Rzptej ordynaryjnych i ekstraordynaryjnych od objęcia przez jmści urzędu podskarbstwa W. Ks. Lit. tak na sejmie szczęśliwej koronacjej in an. 1676 jako też in anno 1677 uchwalonych i prorogowanych do skarbu Rzeczyp. W Ks. Lit. [...] Ad productum przed stanami Rzptej na sejm teraźniejszy zgromadzonemi 1678 sporządzona, AGAD, Nabytki Niedokumentowe Oddziału I (further cit. Nabytki), sygn. 36, k. 380-425.

${ }^{6}$ Zbigniew Hundert, Kilka uwag na temat choragwi petyhorskich w wojskach Rzeczypospolitej w latach 1673-1683, [in:] Homo Militans, t. 2: W pancerzu przez wieki. Z dziejów wojskowości polskiej i powszechnej, ed. Marcin Baranowski, Andrzej GŁadysz, Andrzej NiEwiŃski, Oświęcim 2014, pp. 136-149 (the Belarusian version with supplementations: Nyekal'ki zawvah nakont pyatsihorskikh kharuhvaw uvoyskakh Rechy Paspalitay u 1673-1683 hh. [Некалькi заўваг наконт пяцігорскіх харугваў у войсках Рэчы Паспалітай у 1673-1683 г2.], Arche, 2015, nr 12 (145), pp. 55-73) - here also the synthetic description of the contribution of the Lithuanian petyhorcy to the military actions of the years 1673-1676. Here, it must be noted that the subject matter of the study was not only this formation, but also units of the Lithuanian army in the 1670s, which belonged to the representatives of the Radziwiłłs and Sapiehas, see: Mariusz SAwICKI, Choragwie radziwiłłowskie w II połowie XVII wieku w świetle ksiag litewskich komisji skarbowo-wojskowych, [in:] Radziwiłłowie w służbie Marsa, s. 243-256; idem, Choragwie sapieżyńskie w II połowie XVII wieku w świetle ksiąg litewskich komisji skarbowo-wojskowych, [in:] Vyalikaye Knyastva Litowskaye: palityka, ekanomika, kul'tura: zbornik navukovykh artykulaw и dzvyukh chastkakh, ch. 1, ed. Uladzimir Husaкоw, Minsk 2017 [Вялікае Княства Літоўскае: палітыка, эканоміка, культура: зборнік навуковых артыкулаў у дзвюх частках, ч. 1, ред. Уладзімір Гусакоў, Мінск 2017], pp. 409-418.

${ }^{7}$ Leszek Andrzej Wierzbicki, O zgodę w Rzeczypospolitej. Zjazd warszawski i sejm pacyfikacyjny 1673 roku, Lublin 2005, p. 36; K. BoвıAтүŃski, Michał Kazimierz Pac, p. 276; idem, Wojsko i polityka, p. 511; Zbigniew Hundert, Między buława a tronem. Wojsko koronne w wal- 
conflicting parties of the political conflict and the so called pacification Sejm made the decision to continue the war with the Ottoman Porte, the Grand Duchy of Lithuania was to provide the army of 12,000 soldiers. Eventually, this number was not reached, but Lithuania supported the royal military units with the contingent of over 8,000 soldiers, which was a significant burden for the financial possibilities of the Grand Duchy. It consisted of:

- 5 hussar banners [Polish: choragiew husarska], 571 horse[s];

- 18 banners of the medium cavalry - petyhorcy, 1,980 horses;

- 5 Cossack banners, 524 horses;

- 5 Reiter cavalry cornets [Polish: kornet rajtarski], 482 horses;

- 3 Tatar banners, 327 horses;

- 18 banners of dragoons, 1,669 horses (according to other sources 1,675);

- 6 foot regiments and 7 freicompanies of the German infantry, 1,893 field rations (according to other sources 1,871);

- 6 banners of the Hungarian infantry, 679 field rations ${ }^{8}$.

After the Chocim campaign there took place a division in the Lithuanian army since the majority of soldiers commanded by the voivode of Vilnius and Grand Hetman of Lithuania Michał Kazimierz Pac had left Moldavia and returned home while some of the units (about 200 people) commanded by the sub-chancellor and Field Hetman of Lithuania Michał Kazimierz Radziwiłł stayed on the scene of the military operations. The situation did not affect greatly the composition of the army, but after the session of officers with Grand Hetman in Brześć in December 1673 several banners decided to leave, like e.g. the Cossack banner of Hieronim Teodor Obuchowicz ${ }^{9}$. Nevertheless, the majority of the Lithuanian army remained on duty, and the convocation Sejm of 1674 eventually maintained the size of the army established a year before - 12,000 army remunerations ${ }^{10}$.

ce stronnictwa malkontentów z ugrupowaniem dworskim w latach 1669-1673, Oświęcim 2014, p. 276. See also: Konrad BoBIATYŃski, W walce o hegemonię. Rywalizacja polityczna w Wielkim Księstwie Litewskim w latach 1667-1674, Warszawa 2016, pp. 165-167, 214-215.

${ }^{8} \mathrm{~K}$. Bobiatý́ski, $W$ drodze pod Chocim, pp. 27-47. The composition of the army on the basis of: Zapłata wojsku W.Ks.L. in subsidium Koronie Polskiej in anno 1673 zaciagnionemu, Lietuvos valstybès istorijos archyvas in Vilnius [Office of the Chief Archivist of Lithuania] (further cit. LVIA), fondas Seniei Aktai (further cit. SA) 3444, k. 511-580v; Edward KotŁubaJ, „Dzieje wojenne Polski [...]”, t. 1, cz. 2, Biblioteka Polskiej Akademii Umiejętności i Polskiej Akademii Nauk w Krakowie, sygn. 1404, pp. 164-253.

${ }^{9}$ Pamiętnik Teodora Hieronima Obuchowicza, [in:] Pamiętniki Filipa, Michała i Teodora Obuchowiczów (1630-1707), ed. Henryk Lulewicz, Andrzej Rachuba, Warszawa 2003, p. 414; K. Bobiatý́ski, Michał Kazimierz Pac, pp. 297-298; idem, Wojsko i polityka, pp. 511-512.

${ }^{10}$ K. Bobiatyński, Michał Kazimierz Pac, p. 299. It should be underlined here that treasury bills have been preserved (presented during the Sejm in Grodno in 1678-1679), which allow us to reconstruct the composition and size of the Lithuanian army (according to the registers 
Another retreat of Pac during the Bracław campaign of the king-elect Jan III at the autumn of 1674 had a much more significant influence on the shape of the army of the Grand Duchy of Lithuania. The major part of the Lithuanian forces - including the whole conscription of foreigners - remained in Ukraine with Sobieski and Field Hetman of Lithuania (about 3,000 people), while many officers who so far had been advocates of the voivode of Vilnius now turned away from him ${ }^{11}$. A good example is the ally of the Pac family Grand Marshall of Lithuania Aleksander Hilary Połubiński, who dissolved his hussar banner because, contrary to his order, it had refused to stay with the king in Ukraine, returning to Lithuania with Grand Hetman ${ }^{12}$. The result of Pac's actions was the reestablishment of the division of the Lithuanian army operating prior to 1667 consisting in the split of the army into two independent divisions, which in practice meant taking some part of the army out of the control of Grand Hetman. The situation was maintained until the coronation Sejm, during the sessions of which Jan III did not decide to confront Pac totally - despite the pressure of his brother-in-law Radzwiłl. The reason was that Jan III needed all the Lithuanian army to conduct subsequent military actions against the Ottoman Porte. In fact, the partition into divisions was maintained in 1676 with the reservation that the Field Hetman and his soldiers were to be subordinated to the jurisdiction of the Grand Hetman's mace. The normalisation of the relations between the hetmans took place on the strength of the agreement signed on 30 March $1676^{13}$.

The result of the division in the Lithuanian army at the turn of 1674 and 1675 and the actions of the Sub-Chancellor Radziwiłt, the aim of which was to deprive his older colleague the power over the army, was the creation of various dangerous projects of the army compositions, which historians have assumed to have been the actual army division. It so happened for example with

of the compositions of units) not only during the Chocim campaign, but also during the four subsequent quarters of the service - until November 1674 (see: LVIA, SA 3444, k. 511-617v).

${ }^{11}$ K. BobiatyŃsKi, Michał Kazimierz Pac, pp. 315-319; idem, Wojsko i polityka, pp. 512-514; idem, Stosunki Jana III Sobieskiego $z$ litewska elita władzy $w$ pierwszym okresie rząów (1674-1676), [in:] Sobieski wokół spisków i konfederacji, ed. Mirosław NAGIELSKI, Biblioteka Epoki Nowożytnej, 2015, nr 2, pp. 134-137; idem, W walce o hegemonię, pp. 274-279.

${ }^{12}$ Recently: A. A. Majewski, Aleksander Hilary Polubiński, pp. 432-435; idem, Choragiew husarska marszałka wielkiego litewskiego Aleksandra Hilarego Połubińskiego w latach 1670-1675, [in:] Hortus bellicus. Studia $z$ dziejów wojskowości nowożytnej, ed. Konrad BoвiatyŃski, Przemysław Gawron, Krzysztof Kossarzecki, Dariusz Milewski, Piotr Kroll, Biblioteka Epoki Nowożytnej, 2017, nr 5, pp. 405-420.

${ }^{13}$ Konrad BoвiatyŃski, Spór o prerogatywy buławy wielkiej litewskiej podczas sejmu koronacyjnego Jana III Sobieskiego w 1676 roku, [in:] Król Jan III Sobieski i Rzeczpospolita w latach 1674-1683, ed. Dariusz MiLewski, Warszawa 2016, pp. 155-176. 
the composition of the left wing, which Janusz Wolinski dated for the turn of the years 1674 and 1675 . It seems that it was only a project of the division of the end of 1675, or even the beginning of 1676 since in the cited documents the composition of the army reminds what was found in the registers of accounts of the Sub-Treasurer B. P. Sapieha of $1678 / 1679$ for the quarter from 15 May 1676. For instance, only in this quarter in the register of military units there appear two hussar banners and two banners of petyhorcy of M. K. Radziwiłł designed in the project of the division of the left wing ${ }^{14}$.

Historians had a bigger problem with another composition, in which the Lithuanian army was divided into two wings. Janusz Woliński dates this register for 1675. However, it must be stressed that the composition of the military units presented in the register does not correspond to the bills of the Sub-Treasurer for the quarter of 15 August to 15 November 1675. Supposedly, the register may be the unrealized project of the partition of the Lithuanian army (not all of it) into divisions, which probably came from the beginning of 1684 - the time when the Sub-Cup-Bearer of Lithuania Jan Karol Dolski was accused of the intention to pull out some military units from the commandry of the Voivode of Vilnius and Grand Hetman Kazimierz Jan Sapieha, which he eventually did not manage to do. Anyway, in this edition of Janusz Woliński, we may surely refer to the year $1675^{15}$.

It seems that the greatest quantity of the precious information about the actual composition of both divisions of the Lithuanian army is included in

${ }^{14}$ Komput lewego skrzydła wojska W. Ks. Lit. in opere zostającego, pp. 223-224; por. AGAD, Nabytki, sygn. 36, k. 380-386: "Expenses on the army for the quarter of the service 15 May 15 August 1676” [trans. Agnieszka Chabros]. Konrad Bobiatyński noticed that this composition came from at least the end of 1675 (see: idem, Nieznana litewska relacja o bitwie pod Chocimiem, p. 558, fn. 41). Damian Orłowski in his monograph (Chocim 1673, Warszawa 2007, pp. 168-171) assumed the composition of the division of the left wing taken from the edition of Janusz Woliński, as the soldiers who had stayed with the king in Ukraine at the turn of $1674 / 1675$.

${ }^{15}$ K. Bobiatyński, Stosunki Jana III Sobieskiego, p. 136. Almost all the units enumerated in the register shall be found in the act of the distribution of hiberna tax of March 1684; that is why it may be concluded that the document was written at the beginning of 1684; Komput wojsk W.Ks.L., ad opus belli [1675], pp. 231-232; comp. Komput wojska JKM Wielkiego Księstwa Litewskiego nowego zaciągu do rozdania hiberny w roku 1684 dnia 24 miesiąca marca, [in:] Jan Władysław Poczobut Odlanicki, Pamiętnik (1640-1684), ed. Andrzej RachubA, Warszawa 1987, pp. 349-353; AGAD, Nabytki, sygn. 36, k. 387v-394v: “To this army for the first unpaid quarter of their service 15 August-15 November 1675” [trans. A.C.]. It was noticed in the Belarussian version of the article about 'petyhorcy' that the composition did not refer to the 1680 s (Z. HuNDERT, Nyekal'ki zawvah, p. 67, fn. 42). Earlier, according to the discussed edition, it erroneously assumed that three hussar banners were to have supported the crown hussars in the battle of Lviv / Lesienice of 24 August 1675, see: Z. HunderT, Husaria koronna, pp. 384-385. 
a document now found in the collections of the Archive of the Sanguszko Family in Wawel ${ }^{16}$. It is probable that it presents the situation from the first half of 1675 (or maybe even from the first quarter of 1675) since among the military units of the right wing there appears, among others, the hussar banner of A. H. Połubiński, which - as we remember - had been dissolved upon the order of its patron a few months before, when, along with the Grand Hetman, it withdrew from Ukraine at the end of $1674^{17}$. According to this register, the Lithuanian army consisted of 10,900 horses and:

- 5 hussar rota cavalry or infantry units, 660 horses;

- 20 rota cavalry or infantry units, 2,520 horses;

- 2 cavalry cornets, 200 horses;

- 2 Cossack rota cavalry or infantry units, 240 horses;

- 9 rota cavalry or infantry units, 1,130 horses;

- 9 military units of dragoons, 1,080 horses;

-4 regiments of German infantry, 4 separate squadrons and 15 freicompanies, 3,660 field rations;

- 7 Hungarian rota infantry units, 700 field rations ${ }^{18}$;

The document assigns to the division of the right wing the units consisting of 4110 horses and field rations, while to the division of the left wing $-3,960$ horses and field rations. Such an annotation is missing only next to freicompanies of the German infantry and rota infantry units of Hungary - which in total have 2120 field rations. As can be seen, the size of both divisions must have been comparable, with a minor prevalence of the units of the Grand Hetman.

Subsequent decisions concerning the size of the Lithuanian army to meet the necessity of the war situation were brought by the coronation Sejm of Jan III, which had sessions from 4 February to 4 April 1676. According to what was recorded in the script to the archive: "[...] The Grand Duchy of Lithuania, ruined financially by the enemy, declared painstakingly to save the common motherland, to provide 10,000 soldiers for half a year from 15 May and to introduce taxes to support the Crown in the upcoming war campaign. His Majesty gives orders to the grand hetman of Lithuania that he should accompany the Crown in the struggle against the common enemy. If the peace treaty were to be signed with the enemy in the first or second quarter of the service, upon the decision of the sejm the hetmans of the Grand Duchy of Lithuania are

${ }^{16}$ Archiwum Narodowe w Krakowie [The National Archives in Krakow] (further cit. ANK), Archiwum Sanguszków ze Sławuty (further cit. ASS), sygn. 190, pp. 115-117.

${ }^{17}$ A. A. Majewski, Choragiew husarska, pp. 416-418.

${ }^{18}$ ANK, ASS, sygn. 190, pp. 115-117. 
obliged to dissolve the Lithuanian army so that they do not do harm to Polish territories while marching through them [...]" [trans. A.C. $]^{19}$.

Thus, the Lithuanian army contracted the service for two quarters of 1676. Had the treaties terminating the war been signed earlier, hetmans of Lithuania would have been obliged to dissolve the army. According to the bills of the Sub-Treasurer Sapieha of 1678/1679, the army which started their military service on 15 May 1676, owned 10,300 horses and field rations. It consisted of:

- 5 hussar rota cavalry or infantry units, 660 horses;

- 22 rota banners of the medium cavalry - petyhorcy, 2,670 horses;

- 1 Reiter cavalry rota, 80 horses;

- 2 Cossack rota, 240 horses;

- 10 Tatar rota, 1,090 horses;

- 10 military units of dragoons, 1,180 horses;

- 4 regiments of the German infantry, 3 separate squadrons and 16 freicompanies, 3,620 field rations;

-7 rotas of the Hungarian infantry, 760 field rations ${ }^{20}$.

In comparison with the quarter of 1675 , which was taken into account in the calculations for the Grodno Sejm of 1678/1679, the composition of the army underwent minor modifications. In the quarter of 15 August - 15 November the Lithuanian army consisted of 10,040 horses and field rations and included:

- 4 hussar rota cavalry or infantry units, 540 horses;

- 20 rota banners of the medium cavalry - petyhorcy, 2,430 horses;

- 1 Reiter rota cavalry or infantry units, 100 horses;

- 2 Cossack rota cavalry or infantry units, 240 horses;

- 9 Tatar rota cavalry or infantry units, 1,130 horses;

- 10 military units of dragoons, 1,200 horses;

- 4 regiments of the German infantry, 3 separate squadrons and 14 freicompanies, 3,620 field rations;

- 7 Hungarian rota infantry units, 780 field rations ${ }^{21}$.

As may be seen, in the subsequent quarter of 1676 the Lithuanian army was much weaker since, according to the accounts, it was much less numerous. In order to illustrate this condition, one may use the register of the army from the Warsaw Archive of the Radziwitl Family, which was also edited by Janusz

${ }^{19}$ Skrypt ad archivum W.Ks.Lit., b. m. i d. (Kraków 4 IV 1676), [in:] Materiały do dziejów wojny, SMHW, t. 16: 1970, cz. 1, p. 281.

${ }^{20}$ AGAD, Nabytki, sygn. 36, k. 380-386: "Expenses on the army for the quarter of the service 15 May - 15 August 1676" [trans.A.C.].

${ }^{21}$ Ibid., k. 387v-395: "to this army for the unpaid first term from 15 August to 15 November 1675 the money was paid” [trans. A.C.]. 
Woliński. It includes data, which basically overlap with what said the accounts of B. P. Sapieha ${ }^{22}$. According to the accounts for the quarter of August 1676, the army of the Grand Duchy of Lithuania consisted of merely 5,733 horses and field rations. It included:

- 4 hussar rota cavalry or infantry units, 283 horses;

- 21 rota banners of the medium cavalry - petyhorcy, 1,813 horses;

- 1 Cossack rota cavalry or infantry units, 67 horses;

- 10 Tatar rota cavalry or infantry units, 908 horses;

- 8 military units of dragoons, 676 horses;

- 3 infantry regiments, 3 separate squadrons and 12 freicompanies, 1,480 field rations;

- 5 Hungarian rota infantry units, 506 field rations ${ }^{23}$.

In comparison with the May quarter, the military powers of the Grand Duchy of Lithuania in the so called Zurawno quarter (the period of the so called Żurawno campaign of 24 September to 17 September 1676) had 4,567 fewer field rations. It resulted from the fact that military units and people who had not taken part in the military actions in the Battle of Zurawno, or even had not managed to reach the concentration point near Lviv, were not paid. Moreover, nine out of twenty-one banners of the medium cavalry - petyhor$c y$ - received the Cossack pay (41 zlotys) - their remuneration was not calculated according to the rate of petyhorcy (46 zlotys) because during the war actions they had failed to use lances ${ }^{24}$.

The source edition enclosed below presents the quantity of the units of the Lithuanian army, the service of which was documented in four periods in the years 1675-1676. The document from the Archive of the Sanguszko Family became the foundation to reconstruct the condition of the army in the first half of 1675 and to assign the majority of the units to the division of the left or right wing. The accounts of the Sub-Treasurer B. Sapieha allowed us to reconstruct the composition and the size of the army in three quarters: 15 August - 15 November 1675, 15 May - 15 August 1676 and 15 August - 15 November 1676.

${ }^{22}$ Komput wojska JKM i Rptej W. Ks. Lit., jako in opere zostawało w ćwierci zaczętej od d. 15 augusti, a na dniu 15 novembra kończącej się w r. 1676 w obozie pod Źórawnem, tak i tych choragwi, które in opere byly, AGAD, Archiwum Warszawskie Radziwiłłów (further cit. AR) II, nr 1578, pp. 40-43, druk: Materiaty do dziejów wojny, SMHW, t. 16: 1970, cz. 2, pp. 259-262.

${ }^{23}$ AGAD, Nabytki, sygn. 36, k. 395v-404v: "to this army for the Żurawno quarter from 15 August to 15 November 1675 the money was paid" [trans. A.C.].

${ }^{24}$ Ibid.; Komput wojska JKM i Rptej W. Ks. Lit., AGAD, AR II, nr 1578, pp. 40-43, print: Materiały do dziejów wojny, SMHW, t. 16: 1970, cz. 2, pp. 259-262; Z. HunderT, Kilka uwag, p. 145. 
Table: The composition and size of the military units of the army of the Grand Duchy of Lithuania according to the classification into divisions from the beginning of 1675 and in three quarters of the service in the years $1675-1676$

\begin{tabular}{|c|c|c|c|c|c|}
\hline \multicolumn{6}{|c|}{ Hussar Banners } \\
\hline No. & MilitaRy UNIT & $\begin{array}{l}\text { The } 1^{\text {st }} \text { half } \\
\text { of } 1675^{25}\end{array}$ & $\begin{array}{l}\text { The quarter } \\
\text { of } 15 \mathrm{Au} \text { - } \\
\text { gust - } 15 \\
\text { November } \\
1675^{26}\end{array}$ & $\begin{array}{c}\text { The quarter } \\
\text { of } 15 \text { May - } \\
15 \text { August } \\
1676^{27}\end{array}$ & $\begin{array}{l}\text { The quarter } \\
\text { of } 15 \mathrm{Au}- \\
\text { gust - } 15 \\
\text { November } \\
1676^{28}\end{array}$ \\
\hline 1 & 2 & 3 & 4 & 5 & 6 \\
\hline 1. & $\begin{array}{l}\text { of Michał Kazimierz Pac, the } \\
\text { voivode of Vilnius, Grand } \\
\text { Hetman of Lithuania under } \\
\text { the command of Krzysztof } \\
\text { Białłozor’s, Marshall of Upita }\end{array}$ & $\begin{array}{c}150 \\
\mathrm{R}\end{array}$ & 150 & 150 & 105 \\
\hline 2. & $\begin{array}{c}\text { of Michał Kazimierz } \\
\text { Radziwił, } \\
\text { Sub-Chancellor and Field } \\
\text { Hetman of Lithuania, } \\
\text { under the command of } \\
\text { Samuel Kmicic, } \\
\text { Standard-Bearer of Orsha, } \\
\text { from } 1676 \text { Grand Guardian } \\
\text { of Lithuania }\end{array}$ & $\begin{array}{l}150 \\
\mathrm{~L}\end{array}$ & 150 & 2 & 105 \\
\hline 3. & $\begin{array}{l}\text { The second unit of Field } \\
\text { Hetman of Lithuania, under } \\
\text { the command of Kazimierz } \\
\text { Przyjałgowski, Standard- } \\
\text { Bearer of Dorpat }\end{array}$ & & - & 120 & - \\
\hline 4. & $\begin{array}{l}\text { of Marcjan Ogiński, } \\
\text { voivode of Trakai }\end{array}$ & $\begin{array}{c}120 \\
\mathrm{~L}\end{array}$ & 120 & 120 & 70 \\
\hline 5. & $\begin{array}{l}\text { of Aleksander Hilary } \\
\text { Połubiński, Grand Marshall } \\
\text { of Lithuania, under the } \\
\text { command of Standard-Bearer } \\
\text { of Smoleńsk Aleksander } \\
\text { Rejnold Połubiński }\end{array}$ & $\begin{array}{c}120 \\
\mathrm{R}\end{array}$ & - & - & - \\
\hline
\end{tabular}

${ }^{25}$ The data on the basis: ANK, ASS, sygn. 190, pp. 115-117. R - right wing, L - left wing.

${ }^{26}$ AGAD, Nabytki, sygn. 36, k. 380-386.

${ }^{27}$ Ibid., k. 387v-395.

${ }^{28}$ Ibid., k. 395v-404v. Among the numerical data concerning the banners of 'petyhorcy' in this quarter, the author underlined the data referring to the unit without lancers remunerated on the basis of the Cossack rate. 


\begin{tabular}{|c|c|c|c|c|c|}
\hline 1 & 2 & 3 & 4 & 5 & 6 \\
\hline 6. & $\begin{array}{c}\text { of Krzysztof Zygmunt } \\
\text { Pac, Grand Chancellor of } \\
\text { Lithuania }\end{array}$ & $\begin{array}{c}120 \\
\mathrm{R}\end{array}$ & 120 & 120 & 103 \\
\hline \multicolumn{6}{|c|}{ Banners of the Medium CaVAlRy - PETYHORCY } \\
\hline No. & UNIT & $\begin{array}{l}\text { The } 1^{\text {st }} \text { half } \\
\text { of } 1675\end{array}$ & $\begin{array}{l}\text { The quarter } \\
\text { of } 15 \mathrm{Au}- \\
\text { gust - } 15 \\
\text { November } \\
1675\end{array}$ & $\begin{array}{c}\text { The quarter } \\
\text { of } 15 \text { May - } \\
15 \text { August } \\
1676\end{array}$ & $\begin{array}{c}\text { The quarter } \\
\text { of } 15 \mathrm{Au}- \\
\text { gust - } 15 \\
\text { November } \\
1676\end{array}$ \\
\hline 1 & 2 & 3 & 4 & 5 & 6 \\
\hline 1. & $\begin{array}{c}\text { of Michał K. Pac, voivode } \\
\text { of Vilnius, Grand Hetman } \\
\text { of Lithuania, under } \\
\text { the command of Piotr Pac, } \\
\text { Standard-Bearer of Braslaw }\end{array}$ & $\begin{array}{c}150 \\
\mathrm{R}\end{array}$ & 120 & 120 & 95 \\
\hline 2. & $\begin{array}{l}\text { The second unit of Grand } \\
\text { Hetman of Lithuania, } \\
\text { under the command of Jan } \\
\text { Kazimierz Wołłowicz, } \\
\text { starost of Fejdany }\end{array}$ & $\begin{array}{c}150 \\
\mathrm{R}\end{array}$ & 120 & 120 & 94 \\
\hline 3. & $\begin{array}{l}\text { The third unit of Grand } \\
\text { Hetman of |Lithuania, under } \\
\text { command of Jan Stetkiewicz }\end{array}$ & $\frac{1}{2}+0$ & & 120 & 96 \\
\hline 4. & $\begin{array}{l}\text { of Michał K. Radziwiłł, Sub- } \\
\text { Chancellor and Field Hetman } \\
\text { of Lithuania, under the } \\
\text { command of Michał Karol } \\
\text { Haraburda, Wojski of Slonim }\end{array}$ & $\begin{array}{l}150 \\
\mathrm{~L}\end{array}$ & 150 & 150 & 108 \\
\hline 5. & $\begin{array}{l}\text { The second unit of Field } \\
\text { Hetman of Lithuania }\end{array}$ & - & - & 120 & - \\
\hline 6. & $\begin{array}{c}\text { of Marcjan Ogiński, } \\
\text { Voivode of Trakai }\end{array}$ & $\begin{array}{c}120 \\
\mathrm{~L}\end{array}$ & 120 & 120 & 76 \\
\hline 7. & $\begin{array}{c}\text { of Kazimierz Jan Sapieh, } \\
\text { Voivode of Polotsk }\end{array}$ & $\begin{array}{c}120 \\
\mathrm{~L}\end{array}$ & 120 & 120 & 77 \\
\hline 8. & $\begin{array}{c}\text { of Jan Jacek Ogiński, Voivode } \\
\text { of Mstislaw }\end{array}$ & - & 120 & 120 & 103 \\
\hline 9. & $\begin{array}{c}\text { of Aleksander Hilary } \\
\text { Połubiński, Grand Marshall } \\
\text { of Lithuania }\end{array}$ & $\begin{array}{c}150 \\
\mathrm{R}\end{array}$ & 120 & 120 & $\underline{100}$ \\
\hline 10. & $\begin{array}{c}\text { of Benedykt Paweł Sapieha, } \\
\text { Court Sub-treasurer, later } \\
\text { Grand Sub-Treasurer of } \\
\text { Lithuania }^{29}\end{array}$ & $\begin{array}{c}120 \\
\mathrm{~L}\end{array}$ & 120 & 120 & 106 \\
\hline
\end{tabular}

${ }^{29}$ In the edition of Janusz Woliński - Grand Sub-Treasurer of Lithuania Hieronim Kirszenstein (Materiały do dziejów wojny, SMHW, t. 16: 1970, cz. 2, p. 260). 


\begin{tabular}{|c|c|c|c|c|c|}
\hline 1 & 2 & 3 & 4 & 5 & 6 \\
\hline 11. & $\begin{array}{l}\text { of Michał Antoni Kryszpin } \\
\text { Kirszensztein, Field Clerk of } \\
\text { Lithuania }\end{array}$ & $\begin{array}{c}120 \\
\mathrm{R}\end{array}$ & 120 & 120 & $\underline{49}$ \\
\hline 12. & $\begin{array}{c}\text { of Franciszek Stefan Sapieha, } \\
\text { Equerry of Lithuania }\end{array}$ & $\begin{array}{c}120 \\
\mathrm{~L}\end{array}$ & 120 & 120 & $\underline{85}$ \\
\hline 13. & $\begin{array}{c}\text { of Jan Karol Dolski, Carver, } \\
\text { and from } 1676 \text { Cupbearer } \\
\text { of Lithuania }\end{array}$ & $\begin{array}{c}120 \\
\mathrm{~L}\end{array}$ & 120 & 120 & 101 \\
\hline 14. & $\begin{array}{l}\text { of Bonifacy T. Pac, Guardian, } \\
\text { and from 1676 Quartermaster } \\
\text { of Lithuania }{ }^{30}\end{array}$ & - & 120 & 120 & $\underline{92}$ \\
\hline 15. & $\begin{array}{c}\text { of Krzysztof Potocki, } \\
\text { Cupbearer of Lithuania }\end{array}$ & $\begin{array}{c}120 \\
\mathrm{~L}\end{array}$ & - & - & - \\
\hline 16. & $\begin{array}{c}\text { of Józef Bogusław Słuszka, } \\
\text { Master of the Hunt, and from } \\
1676 \text { Grand Standard-Bearer } \\
\text { of Lithuania }\end{array}$ & $\begin{array}{r}120 \\
\mathrm{~L}\end{array}$ & 120 & 120 & $\underline{99}$ \\
\hline 17. & $\begin{array}{c}\text { of Michał Leon Drucki } \\
\text { Sokoliński, Grand Clerk } \\
\text { of Lithuania. }\end{array}$ & $\begin{array}{c}120 \\
\mathrm{R}\end{array}$ & & - & - \\
\hline 18. & $\begin{array}{l}\text { of Władysław Tyszkiewicz, } \\
\text { starost of Pieniany, and from } \\
1676 \text { Carver of Lithuania }\end{array}$ & $\begin{array}{c}120 \\
\mathrm{R}\end{array}$ & 120 & 120 & $\underline{43}$ \\
\hline 19. & $\begin{array}{c}\text { of Stanisław Lipnicki, Starost } \\
\text { of Sejwy }\end{array}$ & $\begin{array}{r}120 \\
\mathrm{~L} \\
\end{array}$ & 120 & 120 & 74 \\
\hline 20. & $\begin{array}{c}\text { of Jerzy Karol Chodkiewicz, } \\
\text { Starost of Błudnień }\end{array}$ & $\begin{array}{c}120 \\
\mathrm{R}\end{array}$ & 120 & 120 & $\underline{66}$ \\
\hline 21. & $\begin{array}{c}\text { of Stanisław Sapieha, } \\
\text { Starost of Traby }\end{array}$ & $\begin{array}{c}120 \\
\mathrm{~L}\end{array}$ & 120 & 120 & $\underline{79}$ \\
\hline 22. & $\begin{array}{c}\text { of Krzysztof Zbigniew } \\
\text { Vorbek-Lettow, District Judge } \\
\text { of Starodub, Field (military) } \\
\text { Guardian }{ }^{32}\end{array}$ & $\begin{array}{c}120 \\
\mathrm{R}\end{array}$ & 120 & 120 & $\underline{104}$ \\
\hline 23. & $\begin{array}{c}\text { of Hieronim Lacki, Starost of } \\
\text { Merecz [Lit. Merkiné] }\end{array}$ & $\begin{array}{c}120 \\
\mathrm{R}\end{array}$ & 120 & 120 & 77 \\
\hline 24. & $\begin{array}{l}\text { of Michał Kociełł, Starost } \\
\text { of Skirstymoń [Lit. Skirsne- } \\
\text { mune] (at the beginning of } \\
1675 \text { he appears under the } \\
\text { name of his father, Hieronim } \\
\text { S. Kociełł, Chamberlain of } \\
\text { Oszmiany [Ashmyany]) }\end{array}$ & $\begin{array}{c}120 \\
\mathrm{R}\end{array}$ & 120 & 120 & $89^{33}$ \\
\hline
\end{tabular}

${ }^{30}$ In the edition of Janusz Woliński - of Quartermaster of Lithuania Albrycht Ciechanowiecki (ibid.).

${ }^{31}$ In the edition of Janusz Woliński - of Zygmunt Adam Słuszka (ibid.).

${ }^{32}$ In the edition of Janusz Woliński - of Guardian of Lithuania Samuel Kmicic (ibid.).

${ }^{33}$ In the edition of Janusz Woliński - 86 horses (ibid.). 


\begin{tabular}{|c|c|c|c|c|c|}
\hline \multicolumn{6}{|c|}{ Reiter Cavalry } \\
\hline No. & UNIT & $\begin{array}{c}\text { The first } \\
\text { half of } \\
1675\end{array}$ & $\begin{array}{c}\text { Quarter } \\
\text { of } 15 \\
\text { August - } 15 \\
\text { November } \\
1675\end{array}$ & $\begin{array}{c}\text { Quarter of } \\
15 \text { May }-15 \\
\text { August } 1676\end{array}$ & $\begin{array}{c}\text { Quarter } 15 \\
\text { August - } 15 \\
\text { November } \\
1676\end{array}$ \\
\hline 1 & 2 & 3 & 4 & 5 & 6 \\
\hline 1. & $\begin{array}{c}\text { of Michał K. Pac, voivode } \\
\text { of Vilnius, Grand Hetman } \\
\text { of Lithuania }\end{array}$ & $\begin{array}{c}100 \\
\mathrm{R}\end{array}$ & 100 & - & - \\
\hline 2. & $\begin{array}{l}\text { of Michał K. Radziwiłł, Sub- } \\
\text { Chancellor and Field Hetman } \\
\text { of Lithuania }\end{array}$ & $\begin{array}{c}100 \\
\mathrm{~L}\end{array}$ & 100 & 80 & - \\
\hline \multicolumn{6}{|c|}{ Cossack BANNERS } \\
\hline No. & UNIT & $\begin{array}{c}\text { The first } \\
\text { half of } \\
1675\end{array}$ & $\begin{array}{c}\text { Quarter } \\
\text { of } 15 \\
\text { August - } 15 \\
\text { November } \\
1675\end{array}$ & $\begin{array}{c}\text { Quarter of } \\
15 \text { May }-15 \\
\text { August } 1676\end{array}$ & $\begin{array}{c}\text { Quarter } 15 \\
\text { August - } 15 \\
\text { November } \\
1676\end{array}$ \\
\hline 1 & 2 & 3 & 4 & 5 & 6 \\
\hline 1. & $\begin{array}{c}\text { of Stefan Wojciech } \\
\text { Czarniawski, Starost } \\
\text { of Marienhaus }\end{array}$ & $\begin{array}{l}-120 \\
R\end{array}$ & 120 & 120 & 67 \\
\hline 2. & of Samuel Grocholski & $\begin{array}{c}120 \\
\mathrm{~L}\end{array}$ & 120 & 120 & - \\
\hline \multicolumn{6}{|c|}{ TATAR BANNERS } \\
\hline No. & UNIT & $\begin{array}{c}\text { The first } \\
\text { half of } \\
1675\end{array}$ & $\begin{array}{c}\text { Quarter } \\
\text { of } 15 \\
\text { August - } 15 \\
\text { November } \\
1675\end{array}$ & $\begin{array}{c}\text { Quarter of } \\
15 \text { May }-15 \\
\text { August } 1676\end{array}$ & $\begin{array}{c}\text { Quarter } 15 \\
\text { August - } 15 \\
\text { November } \\
1676\end{array}$ \\
\hline 1 & 2 & 3 & 4 & 5 & 6 \\
\hline 1. & $\begin{array}{c}\text { of Michał K. Pac, Voivode } \\
\text { of Vilnius, Grand Hetman } \\
\text { of Lithuania }\end{array}$ & $\begin{array}{c}200 \\
\mathrm{R}\end{array}$ & 200 & 150 & 139 \\
\hline 2. & $\begin{array}{c}\text { of Michał K. Radziwiłł, Sub- } \\
\text { Chancellor and Field Hetman } \\
\text { of Lithuania }\end{array}$ & $\begin{array}{c}120 \\
\mathrm{~L}\end{array}$ & 120 & 120 & 104 \\
\hline 3. & $\begin{array}{l}\text { of Aleksander H. Połubiński, } \\
\text { Grand Marshall of Lithuania }\end{array}$ & $\begin{array}{c}120 \\
\mathrm{R}\end{array}$ & 120 & 120 & 64 \\
\hline 4. & $\begin{array}{c}\text { of Michał A. Kryszpin } \\
\text { Kirszensztein, Field Clerk } \\
\text { of Lithuania }\end{array}$ & $\begin{array}{c}120 \\
\mathrm{R}\end{array}$ & 120 & 100 & 89 \\
\hline
\end{tabular}




\begin{tabular}{|c|c|c|c|c|c|}
\hline 1 & 2 & 3 & 4 & 5 & 6 \\
\hline 5. & $\begin{array}{c}\text { of Bonifacy T. Pac, Guardian, } \\
\text { and from 1676 Quartermaster } \\
\text { of Lithuania }\end{array}$ & - & 100 & 100 & 95 \\
\hline 6. & $\begin{array}{c}\text { of Antoni Paweł } \\
\text { Pierzchowski, Steward } \\
\text { of Chełm, and from August } \\
1675 \text { of Krzysztof Białłozor, } \\
\text { Marshall of Upita }\end{array}$ & $\begin{array}{c}100 \\
\mathrm{~L}\end{array}$ & 100 & 100 & 93 \\
\hline 7. & $\begin{array}{l}\text { of Krzysztofa Z. Vorbek- } \\
\text { Lettow, District Judge } \\
\text { of Starodub, Field } \\
\text { (military) Guardian }\end{array}$ & $\begin{array}{c}150 \\
\mathrm{R}\end{array}$ & 150 & 120 & 97 \\
\hline 8. & of Florian Szlagier & $\begin{array}{c}120 \\
\mathrm{~L}\end{array}$ & 120 & 100 & 74 \\
\hline 9. & $\begin{array}{l}\text { of Eliasz Niekraszewicz } \\
\text { Treasurer of Brześć }\end{array}$ & $\frac{100}{\mathrm{~L}}$ & 100 & 100 & 83 \\
\hline 10. & $\begin{array}{c}\text { of Aleksander(?) Murzy } \\
\text { Szczucki }\end{array}$ & $\begin{array}{c}100 \\
\mathrm{~L}\end{array}$ & $\sqrt{-51}$ & - & - \\
\hline \multicolumn{6}{|c|}{ DRAGOON UNITS } \\
\hline No. & UnIT & $\begin{array}{c}\text { The first } \\
\text { half of } \\
1675\end{array}$ & $\begin{array}{c}\text { Quarter } \\
\text { of } 15 \\
\text { August - } 15 \\
\text { November } \\
1675\end{array}$ & $\begin{array}{c}\text { Quarter of } \\
15 \text { May }-15 \\
\text { August } 1676\end{array}$ & $\begin{array}{c}\text { Quarter } \\
15 \text { August - } \\
15 \text { November } \\
1676\end{array}$ \\
\hline 1 & 2 & 3 & 4 & 5 & 6 \\
\hline 1. & $\begin{array}{c}\text { of Michał K. Pac, voivode } \\
\text { of Vilnius, Grand Hetman } \\
\text { of Lithuania }\end{array}$ & $\begin{array}{c}200 \\
\mathrm{R}\end{array}$ & 200 & 200 & 200 \\
\hline 2. & $\begin{array}{l}\text { of Michał K. Radziwiłł, Sub- } \\
\text { Chancellor and Field Hetman } \\
\text { of Lithuania }\end{array}$ & $\begin{array}{c}200 \\
L\end{array}$ & 200 & 200 & 76 \\
\hline 3. & $\begin{array}{l}\text { of Kazimierz J. Sapieha, } \\
\text { Voivode of Polotsk }\end{array}$ & $\begin{array}{c}80 \\
\mathrm{~L}\end{array}$ & 100 & 100 & - \\
\hline 4. & $\begin{array}{l}\text { of Jan J. Ogiński, Voivode } \\
\text { of Mstislaw }\end{array}$ & - & 100 & 80 & 47 \\
\hline 5. & $\begin{array}{l}\text { of Krzysztof Z. Pac, Grand } \\
\text { Chancellor of Lithuania. }\end{array}$ & $\begin{array}{c}80 \\
\mathrm{R}\end{array}$ & 80 & 80 & - \\
\hline
\end{tabular}

${ }^{34}$ See the manifestation of Stefan Podolewski, Lieutenant of the banner under the command of A. P. Pierzchowski describing the circumstances of the unit being taken over in the summer of 1675 by the advocates of Grand Hetman (LVIA, SA 4691, k. 247-250), also the document confirming the conflict between Pierzchowski and the entourage of standard-bearers (Нацыянальны Гістарычны Apхіў Беларусі [National Historical Archives of Belarus], Мінск [Minsk], f. 1705, op. 1, nr 19, pp. 2611-2614). 
[169] The Composition of the Army of the Grand Duchy of Lithuania...

\begin{tabular}{|c|c|c|c|c|c|}
\hline 1 & 2 & 3 & 4 & 5 & 6 \\
\hline 6. & $\begin{array}{c}\text { of Benedykt P. Sapieha, Court } \\
\text { Sub-Tresurer, later Grand } \\
\text { Treasurer of Lithuania }\end{array}$ & $\begin{array}{c}80 \\
\mathrm{~L}\end{array}$ & 100 & 100 & $100^{35}$ \\
\hline 7. & $\begin{array}{c}\text { of Jan K. Dolski, Carver, } \\
\text { and from } 1676 \text { Cupbearer } \\
\text { of Lithuania }\end{array}$ & $\begin{array}{c}80 \\
\mathrm{~L}\end{array}$ & 80 & 80 & 66 \\
\hline 8. & $\begin{array}{l}\text { of Krzysztof Potocki, } \\
\text { Cupbearer of Lithuania }\end{array}$ & $\begin{array}{c}100 \\
\mathrm{~L}\end{array}$ & - & - & - \\
\hline 9. & $\begin{array}{l}\quad \text { of Maciej Kazimierz } \\
\text { Gosiewski, Artillery General }\end{array}$ & $\begin{array}{c}160 \\
\text { with the } \\
\text { annotation } \\
\text { "at a cannon" }\end{array}$ & 160 & 160 & 82 \\
\hline 10. & $\begin{array}{c}\text { of Krzysztof Zbigniew } \\
\text { Vorbek-Lettow, District Judge } \\
\text { of Starodub, Field (military) } \\
\text { Guardian }\end{array}$ & $\begin{array}{c}100 \\
\mathrm{R} \\
\end{array}$ & 100 & 100 & 36 \\
\hline 11. & $\begin{array}{c}\text { of Jan Kazimierz Pac, Captain } \\
\text { of His Majesty }\end{array}$ & +1 & 100 & 100 & 69 \\
\hline \multicolumn{6}{|c|}{ REgImEnts, SQUAdrons, FREICOMPANIES OF THE GERMan INFANTRY } \\
\hline No. & UNIT & $\begin{array}{c}\text { The first } \\
\text { half of } \\
1675\end{array}$ & $\begin{array}{c}\text { Quarter } \\
\text { of } 15 \\
\text { August - } 15 \\
\text { November } \\
1675\end{array}$ & $\begin{array}{c}\text { Quarter of } \\
15 \text { May }-15 \\
\text { August } 1676\end{array}$ & $\begin{array}{c}\text { Quarter } 15 \\
\text { August - } 15 \\
\text { November } \\
1676\end{array}$ \\
\hline 1 & 2 & 3 & 4 & 5 & 6 \\
\hline 1. & $\begin{array}{c}\text { of Michał K. Pac, Voivode } \\
\text { of Vilnius, Grand Hetman } \\
\text { of Lithuania }\end{array}$ & $\begin{array}{c}600 \\
\mathrm{R}\end{array}$ & 600 & 600 & 359 \\
\hline 2. & $\begin{array}{l}\text { of Michał K. Radziwiłł, Sub- } \\
\text { Chancellor and Field Hetman } \\
\text { of Lithuania }\end{array}$ & $\begin{array}{c}400 \\
\mathrm{~L}\end{array}$ & 600 & 600 & - \\
\hline 3. & $\begin{array}{c}\text { of Marcjan Ogiński, } \\
\text { Voivode of Trakai }\end{array}$ & $\begin{array}{c}320 \\
\mathrm{~L}\end{array}$ & 320 & 320 & 136 \\
\hline 4. & $\begin{array}{c}\text { of Aleksander Hilary } \\
\text { Połubiński, Grand Marshall } \\
\text { of Lithuania }\end{array}$ & $\begin{array}{c}320 \\
\mathrm{R}\end{array}$ & 320 & 320 & 248 \\
\hline 5. & $\begin{array}{c}\text { of Krzysztofa Z. Pac, Grand } \\
\text { Chancellor of Lithuania }\end{array}$ & $\begin{array}{c}160 \\
\mathrm{R}\end{array}$ & 160 & 160 & 89 \\
\hline 6. & $\begin{array}{c}\text { of Michał A. Kryszpin } \\
\text { Kirszensztein, Field Clerk } \\
\text { of Lithuania }\end{array}$ & $\begin{array}{c}160 \\
\mathrm{R}\end{array}$ & 160 & 160 & 26 \\
\hline
\end{tabular}

${ }^{35}$ In the edition of Janusz Woliński - 80 horses (Materialy do dziejów wojny, SMHW, t. 16: 1970, cz. 2, p. 261). 


\begin{tabular}{|c|c|c|c|c|c|}
\hline 1 & 2 & 3 & 4 & 5 & 6 \\
\hline 7. & $\begin{array}{l}\text { of Kazimierz Kłokocki, } \\
\text { Pantler of Płock }{ }^{36}\end{array}$ & $\begin{array}{c}240 \\
\mathrm{~L}\end{array}$ & 240 & 200 & 113 \\
\hline 8. & $\begin{array}{c}\text { of Jan J. Ogiński, Voivode } \\
\text { of Mstislaw }\end{array}$ & - & - & 80 & - \\
\hline 9. & $\begin{array}{c}\text { of Stanisław Kazimierz } \\
\text { Radziwiłł, Pantler } \\
\text { of Lithuania }\end{array}$ & $\begin{array}{c}200 \\
L\end{array}$ & - & - & - \\
\hline 10. & $\begin{array}{c}\text { of Jan Karol Dolski, Carver, } \\
\text { and from } 1676 \text { Cupbearer } \\
\text { of Lithuania }\end{array}$ & 80 & 80 & 80 & 37 \\
\hline 11. & $\begin{array}{c}\text { of Franciszek Stefan Sapieha, } \\
\text { Equerry of Lithuania }\end{array}$ & 80 & 80 & 80 & 18 \\
\hline 12. & $\begin{array}{l}\text { of Bonifacy T. Pac, Guardian, } \\
\text { and from 1676 Quartermaster } \\
\text { of Lithuania }\end{array}$ & 80 & 80 & 80 & 67 \\
\hline 13. & $\begin{array}{c}\text { of Józef Bogusław Słuszka, } \\
\text { Master of the Hunt, and from } \\
1676 \text { Grand Standard-Bearer } \\
\text { of Lithuania }\end{array}$ & 80 & 80 & 80 & 52 \\
\hline 14. & $\begin{array}{c}\text { of Michał Leon Drucki } \\
\text { Sokoliński, Grand Clerk } \\
\text { of Lithuania. }\end{array}$ & 80 & 80 & 80 & 41 \\
\hline 15. & $\begin{array}{l}\text { of Władysław Tyszkiewicz, } \\
\text { Starost of Pieniany, and from } \\
\text { 1676 Carver of Lithuania }\end{array}$ & 80 & 80 & 80 & 4 \\
\hline 16. & $\begin{array}{l}\text { of Samuel Kmicic, Standard- } \\
\text { Bearer of Orsha, from } 1676 \\
\text { Grand Guardian of Lithuania }\end{array}$ & - & - & 80 & - \\
\hline 17. & $\begin{array}{l}\text { of Piotr Rudomina Dusiacki, } \\
\text { Starost of Starodub }\end{array}$ & $\begin{array}{l}80 \\
\text { with the } \\
\text { annotation } \\
\text { "in Vilnius" }\end{array}$ & 80 & 60 & 60 \\
\hline 18. & $\begin{array}{l}\text { of Krzysztof Białłozor, } \\
\text { Marshall }{ }^{37} \text { of Upita }\end{array}$ & 120 & 120 & 100 & $65^{38}$ \\
\hline 19. & $\begin{array}{l}\text { of Stanisław Lipnicki, } \\
\text { Starost of Sejwy }\end{array}$ & 80 & 80 & 80 & 52 \\
\hline 20. & $\begin{array}{l}\text { of Jerzy Karol Chodkiewicz, } \\
\text { Starost of Błudnień }\end{array}$ & 80 & 80 & 80 & 35 \\
\hline 21. & $\begin{array}{l}\text { of Stanisław Sapieha, } \\
\text { Starost of Traby }\end{array}$ & 80 & 80 & 80 & 18 \\
\hline
\end{tabular}

${ }^{36}$ In the edition of Janusz Woliński - of Pantler of Płock Władysław Łoś (ibid.).

${ }^{37}$ In the accounts for the August quarter of 1675 and 1676 the unit is presented as commanded by the starost of Upita (in 1678 the office was taken over by Białłozor).

${ }^{38}$ In the edition of Janusz Woliński - 68 field rations (Materiały do dziejów wojny, SMHW, t. 16: 1970, cz. 2, p. 262). 


\begin{tabular}{|c|c|c|c|c|c|}
\hline 1 & 2 & 3 & 4 & 5 & 6 \\
\hline 22. & $\begin{array}{c}\text { of Jan Andrzej Plater, Starost } \\
\text { of Dyneburg }\end{array}$ & $\begin{array}{c}100 \\
\text { with the } \\
\text { annotation } \\
\text { "in Dyne- } \\
\text { burg" }\end{array}$ & 100 & 60 & 60 \\
\hline 23. & $\begin{array}{c}\text { of Leonard Gabriel Pociej, } \\
\text { District Judge of Brześć }\end{array}$ & 80 & 80 & 80 & - \\
\hline 24. & $\begin{array}{l}\text { of Konstanty Jan Szujski, } \\
\text { District Clerk of Brześć }\end{array}$ & 80 & 80 & 80 & - \\
\hline 25. & $\begin{array}{c}\text { of Gedeon Aleksander } \\
\text { Chalecki, Starost } \\
\text { of Nowosielsk }\end{array}$ & 80 & - & - & - \\
\hline \multicolumn{6}{|c|}{ HUNGARIAN INFANTRY } \\
\hline No. & UNIT & $\begin{array}{c}\text { The first } \\
\text { half of } \\
1675\end{array}$ & $\begin{array}{c}\text { Quarter } \\
\text { of } 15 \\
\text { August - } 15 \\
\text { November } \\
1675\end{array}$ & $\begin{array}{c}\text { Quarter of } \\
15 \text { May }-15 \\
\text { August } 1676\end{array}$ & $\begin{array}{c}\text { Quarter } 15 \\
\text { August - } 15 \\
\text { November } \\
1676\end{array}$ \\
\hline 1 & 2 & 3 & 4 & 5 & 6 \\
\hline 1. & $\begin{array}{c}\text { of Michał K. Pac, Voivode } \\
\text { of Vilnius, Grand Hetman } \\
\text { of Lithuania }\end{array}$ & 200 & 200 & 200 & 200 \\
\hline 2. & $\begin{array}{c}\text { of Michał K. Radziwiłł, Sub- } \\
\text { Chancellor and Field Hetman } \\
\text { of Lithuania }\end{array}$ & 100 & 100 & 100 & - \\
\hline 3. & $\begin{array}{c}\text { Janissary Banner of Field } \\
\text { Hetman of Lithuania }\end{array}$ & - & 100 & 80 & - \\
\hline 4. & $\begin{array}{c}\text { of Marcjan Ogiński, } \\
\text { Voivode of Trakai }\end{array}$ & 100 & 100 & 100 & 90 \\
\hline 5. & $\begin{array}{c}\text { of Kazimierz J. Sapieha, } \\
\text { Voivode of Polotsk }\end{array}$ & 100 & 100 & 100 & 53 \\
\hline 6. & $\begin{array}{c}\text { of Aleksander Hilary } \\
\text { Połubiński, Grand Marshall } \\
\text { of Lithuania }\end{array}$ & 100 & 100 & 100 & 88 \\
\hline 7. & $\begin{array}{c}\text { Banner of the Zaporozhian } \\
\text { Cossacks of Michał K. Pac, } \\
\text { Voivode of Vilnius and Grand } \\
\text { Hetman of Lithuania }\end{array}$ & 100 & - & 80 & 70 \\
\hline
\end{tabular}

trans. by Agnieszka Chabros

Received 22 November 2017

Received in revised form 13 March 2018

Accepted 25 March 2018 
Dr hab. Konrad Bobiatyński

Historical Institute

Warsaw University

e-mail: $k \_b o b @ w p . p l$

ORCID ID: 0000-0002-9832-3048

Dr Zbigniew Hundert

Institute of History

Cardinal Stefan Wyszyński University

e-mail: zb.hundert@gmail.com

ORCID ID: 0000-0002-5088-2465

\section{The Composition of the Army of the Grand Duchy \\ of Lithuania during the War With TURKey (1675-1676) \\ IN THE Light of FinanCial AND Military files}

\section{Summary}

Key words: the Polish-Turkish war 1672-1676, the Lithuanian army, the Old Polish army

The aim of this source edition is to reconstruct thoroughly the composition of the Lithuanian army in the years 1675-1676 during the next stage of the war between the Polish-Lithuanian Commonwealth with Turkey (1672-1676), in which the Grand Duchy of Lithuania took an active part. The source basis used to reconstruct the composition of the army during three quarters of the service in the years 1675-1676 were the accounts of the Grand Sub-Treasurer of Lithuania Benedykt Paweł Sapieha, which were prepared for the Grodno Sejm of 1678-1679. They include the expenditure of the treasury on individual units of the Lithuanian army in the quarters from 15 August to 15 November 1675 and two quarters of 1676 - in total from 15 May to 15 November 1676. In order to present the composition of the army in the first half of 1675 the authors used the list of the Lithuanian military units found in the Sanguszko Archive in Cracow.

Die Zusammensetzung Der Armee

Des Grossfürstentums Litauen Zur Zeit Des Türkenkriegs 1675/76 IM LiCHT VON FinANZ- UND MiLitÄRAKTEN

\section{Zusammenfassung}

Schlüsselwörter: polnisch-türkischer Krieg 1672-1676, litauisches Heer, altpolnisches Heerwesen

Ziel der vorliegenden Quellenedition ist eine genaue Rekonstruktion der Zusammensetzung der litauischen Armee in den Jahren 1675-1676, in einer bestimmten 
Phase des Kriegs der Adelsrepublik gegen das Osmanische Reich (1672-1676), an dem sich das Großfürstentum Litauen aktiv beteiligte. Als Quellengrundlage für eine Rekonstruktion der Zusammensetzung des Heers während dreier Dienstquartale in den Jahren 1675/76 dienten Abrechnungen des litauischen Großkämmerers Benedykt Paweł Sapieha, die für den Sejm in Grodno von 1678/79 vorbereitet wurden. Sie enthielten die Ausgaben des Staatsschatzes für die einzelnen Einheiten der litauischen Armee im Quartal vom 15. August bis zum 15. November 1675 sowie für die zwei Quartale zwischen dem 15. Mai und dem 15. November 1676. Dagegen benutzten die Autoren für die Feststellung der Zusammensetzung der Armee in der ersten Hälfte des Jahres 1675 eine Aufstellung der litauischen Einheiten, die sich im Archiv der Familie Sanguszko in Krakau befindet.

\section{BIBLIOGRAPHY}

Bobiatyński, Konrad. Michał Kazimierz Pac. Wojewoda wileński, hetman wielki litewski. Warszawa: Neriton, 2008.

Bobiatyński, Konrad. "Michał Kazimierz Radziwiłł jako hetman polny litewski (1668-1680)." In Radziwiłłowie w służbie Marsa, edited by Mirosław Nagielski, Karol Żojdź, 229-241. Warszawa: DiG, 2017.

Bobiatyński, Konrad. "Nieznana litewska relacja o bitwie pod Chocimiem w 1673 roku.” Przegląd Historyczny 106/3 (2015): 551-563.

Bobiatyński, Konrad. "Spór o prerogatywy buławy wielkiej litewskiej podczas sejmu koronacyjnego Jana III Sobieskiego w 1676 roku.” In Król Jan III Sobieski i Rzeczpospolita $w$ latach 1674-1683, edited by Dariusz Milewski, 155-176. Warszawa: Muzeum Pałacu Króla Jana III w Wilanowie, 2016.

Bobiatyński, Konrad. "Stosunki Jana III Sobieskiego z litewską elitą władzy w pierwszym okresie rządów (1674-1676).” In Sobieski wokót spisków i konfederacji, edited by Mirosław Nagielski. Biblioteka Epoki Nowożytnej 2 (2015): 129-143.

Bobiatyński, Konrad. "Voyska i palityka - nyekal'ki zawvah pra wdzyel voyska Vyalikaha Knyastva Litowskaha w kampaniyakh suprats' turkaw i tataraw u 70-kh hh. XVII st." Arche 6 (2012): 387-402.

Bobiatyński, Konrad. "W drodze pod Chocim. Litewskie przygotowania do wojny przeciwko Turkom w 1673 roku." In Studia z dziejów Wielkiego Księstwa Litewskiego (XVI-XVIII wieku), edited by Mirosław Nagielski, Sławomir Górzyński, 27-47. Warszawa: DiG, 2014.

Bobiatyński, Konrad. W walce o hegemonię. Rywalizacja polityczna w Wielkim Księstwie Litewskim w latach 1667-1674. Warszawa: Neriton, 2016.

Bobiatyński, Konrad. "Wojsko i polityka - kilka uwag o udziale armii litewskiej w kampaniach przeciwko Turkom i Tatarom w latach 70. XVII w." In Rzeczpospolita państwem wielu narodowości i wyznań. XVI-XVIII wiek, edited by Tomasz Ciesielski, Anna Filipczak-Kocur, 503-519. Warszawa-Opole: DiG, 2008.

Codello, Aleksander. "Litwa wobec wojny z Turcją 1672-1676." Studia i Materiały do Historii Wojskowości” 13/1 (1970): 136-159.

Filipczak-Kocur, Anna. "Od Chocimia do Żórawna (Żurawna). Finansowy udział Wielkiego Księstwa Litewskiego w kampaniach wojennych 1673-1676.” In Studia 
Historyczno-Wojskowe, vol. 3, edited by Tomasz Ciesielski, 130-137. Zabrze: Inforteditions, 2009.

Filipczak-Kocur, Anna. "The financial contribiution of the Grand Duchy of Lithuania to the war campaigns in the years 1673-1676." In Prablyemy intehratsyi i inkarparatsyi $w$ razvitstsi Tsentaral'nay $i$ Uskhodnyay Yewropy $w$ pyeryyaad rannyaha Novaha chasu, edited by Stsyapan Sokal, Andrey Yanushkyevich, 358-366. Minsk: BIP - Instytut pravaznay̆stva. Pol'ski Instytut u Minsku, 2010.

Hundert, Zbigniew. Husaria koronna w wojnie polsko-tureckiej 1672-1676. Oświęcim: Napoleon V, 2014, ed. 2.

Hundert, Zbigniew. "Kilka uwag na temat chorągwi petyhorskich w wojskach Rzeczypospolitej w latach 1673-1683." In Homo Militans, vol. 2: W pancerzu przez wieki. Z dziejów wojskowości polskiej i powszechnej, edited by Marcin Baranowski, Andrzej Gładysz, Andrzej Niewiński, 136-149. Oświęcim: Napoleon V, 2014.

Hundert, Zbigniew. Między buława a tronem. Wojsko koronne $w$ walce stronnictwa malkontentów z ugrupowaniem dworskim w latach 1669-1673. Oświęcim: Napoleon V, 2014.

Hundert, Zbigniew. "Nyekal'ki zawvah nakont pyatsihorskikh kharuhvaw uvoyskakh Rechy Paspalitay u 1673-1683 hh.” Arche 12 (2015): 55-73.

Majewski, Andrzej Adam. Aleksander Hilary Połubiński (1626-1679). Marszałek wielki litewski. Warszawa: Neriton, 2017.

Majewski, Andrzej Adam. "Chorągiew husarska marszałka wielkiego litewskiego Aleksandra Hilarego Połubińskiego w latach 1670-1675." In Hortus bellicus. Studia z dziejów wojskowości nowożytnej, edited by Konrad Bobiatyński, Przemysław Gawron, Krzysztof Kossarzecki, Dariusz Milewski, Piotr Kroll. Biblioteka Epoki Nowożytnej, 5 (2017): 405-420.

Malejka, Arkadiusz. "Zdobycie Pawołoczy (1675 r.) - epizod z wojny polsko-tureckiej." In Traktaty karłowickie 1699 roku $i$ ich następstwa, edited by Ilona Czamańska, Witold Szulc. Balcanica Posnaniensia. Acta et Studia 13 (2003): 85-93.

“Materiały do dziejów wojny polsko-tureckiej 1672-1676." edited by Janusz Woliński. Studia i Materiały do Historii Wojskowości 15/2 (1969): 209-234 and 16/1-2 (1970): 233-262.

Orłowski, Damian. Chocim 1673. Warszawa: Bellona, 2007.

"Pamiętnik Teodora Hieronima Obuchowicza." In Pamiętniki Filipa, Michała i Teodora Obuchowiczów (1630-1707), edited by Henryk Lulewicz, Andrzej Rachuba, 410-422. Warszawa: DiG, 2003.

Poczobut Odlanicki, Jan Władysław. Pamiętnik (1640-1684), edited by Andrzej Rachuba. Warszawa: Czytelnik, 1987.

Sawicki, Mariusz. "Chorągwie radziwiłłowskie w II połowie XVII wieku w świetle ksiąg litewskich komisji skarbowo-wojskowych.” In Radziwiłłowie w służbie Marsa, edited by Mirosław Nagielski, Karol Żojdź, 243-256. Warszawa: DIG, 2017.

Sawicki, Mariusz. "Chorągwie sapieżyńskie w II połowie XVII wieku w świetle ksiąg litewskich komisji skarbowo-wojskowych." In Vyalikaye Knyastva Litowskaye: palityka, ekanomika, kul'tura: zbornik navukovykh artykulaw u dzvyukh chastkakh, vol. 1, edited by Uladzimir Husakow, 409-418. Minsk: Belaruskaya navuka, 2017. 
[175] The Composition of the Army of the Grand Duchy of Lithuania...

“Sobiesciana z 1675 r.", edited by Janusz Woliński. Przegląd Historyczno-Wojskowy 5/2 (1932): 223-242.

Wagner, Marek. Wojna polsko-turecka 1672-1676. vol. 1-2. Zabrze: Inforteditions, 2009.

Wierzbicki, Leszek Andrzej. O zgodę w Rzeczypospolitej. Zjazd warszawski i sejm pacyfikacyjny 1673 roku. Lublin: Marie Curie-Skłodowska University Press, 2005.

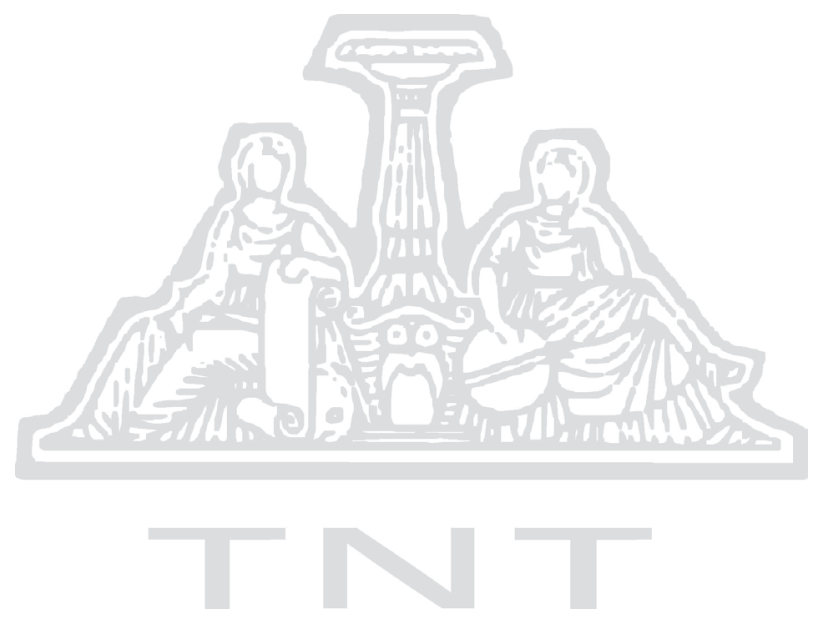

